\title{
Total biomass and essential oil composition of Ocimum gratissimum L. in response to broiler litter and phosphorus
}

\author{
PESSOA, S.M. '; HEREDIA ZÁRATE, N.A."; VIEIRA, M.C."*; CARDOSO, C. A. L.2; POPPI, N.R. ${ }^{3 ;}$ FORMAGIO, \\ A.S.N.'; SILVA, L.R. ${ }^{4}$ \\ Universidade Federal da Grande Dourados, Faculdade de Ciências Agrárias, Cx. Postal 533, 79804-970 \\ Dourados, MS, Brazil; *vieiracm@terra.com.br; 2Universidade Estadual de Mato Grosso do Sul, Centro de \\ Pesquisa em Biodiversidade, Cx. Postal 351, 79804-970 Dourados, MS; 3 Universidade Federal de Mato Grosso \\ do Sul, Laboratório de Química, Cx. Postal 641, 79100-000 Campo Grande, MS; 4 Universidade Federal da \\ Grande Dourados, Faculdade de Engenharia, Cx. Postal 533, 79804-970 Dourados, MS
}

\begin{abstract}
The aim of this experiment was to evaluate the biomass yield and chemical composition of the essential oil of clove basil in response to doses of broiler litter $(0,5,10,15$ and $\left.20 \mathrm{t} \mathrm{ha}^{-1}\right)$ added in presence of triple superphosphate (200 kg ha-1) or without it. Before the first harvest, the height of the plants increased significantly $(34.42 \mathrm{~cm})$ when 15 tonnes ha-1 $^{-1}$ broiler litter were added to the soil. However, after resprouting, the plant heights ranged only as a function of the vegetative cycle, with maximum height $(76.0 \mathrm{~cm})$ observed at 60 days. Phosphate fertilization also significantly influenced the leaf area $\left(1.771 \mathrm{~cm}^{2}\right.$ plant-1) during the first harvest. The fresh weight of leaves increased linearly in response to the addition of broiler litter (20 ton ha-1) with maximum yields of 1,709 and 7,140 kg ha-1 during the first harvest and regrowth, respectively. On average, the oil content of the leaves was $0.7 \%$, with maximum performance (3.8 $\left.\mathrm{L} \mathrm{ha}^{-1}\right)$ when 20 tonnes ha-1 of broiler litter were added on the soil. Eugenol was found to be the major compound of the essential oil $(71.65 \%)$.
\end{abstract}

Key words: clove basil, chemical composition, medicinal plant, organic residue, triple superphosphate.

RESUMO. Produção de biomassa e composição do óleo essencial de Ocimum gratissimum L. cultivado em solo com cama-de-frango e fósforo. O objetivo do trabalho foi avaliar a produção de biomassa e a composição do óleo essencial da alfavaca-cravo cultivada com adição ao solo de cama-de-frango de corte, na ausência ou presença de fósforo. Foram estudadas cinco doses de cama-de-frango semi-decomposta $(0,5,10,15$ e 20 tha-1), na ausência ou presença de fósforo (200 kg ha-1), na forma de superfosfato triplo. A altura das plantas na primeira colheita foi maior sob a dose de $15 \mathrm{tha}^{-1}$ de cama-de-frango $(34,42 \mathrm{~cm})$, ou sem o uso de fósforo $(32,4 \mathrm{~cm})$; na rebrota, a altura variou apenas em função do ciclo, sendo máxima $(76,0$ $\mathrm{cm}$ ) aos 60 dias após a rebrota. A adubação fosfatada influenciou significativamente a área foliar da primeira colheita, que foi maior com fósforo $\left(1.771 \mathrm{~cm}^{2}\right.$ planta-1). As produções de massas frescas de folhas cresceram linearmente com as doses de cama-de-frango, com máximas de 1.709 e $7.140 \mathrm{~kg} \mathrm{ha}^{-1}$ na primeira colheita e na rebrota, respectivamente, sob $20 \mathrm{t} \mathrm{ha}^{-1}$. O teor de óleo essencial foi em média de $0,7 \%$ e o rendimento máximo de $3,8 \mathrm{~L} \mathrm{ha-1}$ sob a dose de $20 \mathrm{t} \mathrm{ha}^{-1}$ de cama-de-frango; o principal constituinte foi o eugenol, com teor médio de $71,65 \%$.

Palavras-chave: alfavaca-cravo, composição química, planta medicinal, resíduo orgânico, superfosfato triplo.

\section{INTRODUCTION}

Ocimum gratissimum L. (Lamiaceae), popularly known as clove-basil, is a perennial species original from Africa and widely cultivated in Brazil. The plant is shrub and woody, measuring $0.50-2.5 \mathrm{~m}$. Its brunches are quadrangular and pubescent and the leaves are opposite and petiolate, hardly aromatic. The inflorescence can be terminal or axillar, white or white-green color and the fruit is a dry shell with four seeds (Albuquerque \& Andrade, 1998). 
The leaves are used in popularly medicine for treatment of rheumatism, paralysis, epilepsy and mental illness. Besides, the presence of active compounds also characterizes it as a natural insecticide, nematicide, fungicide and antimicrobial (Effraim et al., 2001).

Studies on the pharmacological properties of the essential oil reported its activity against several high pathogenicity microorganisms, as Staphylococcus aureus, S. typhimurium, Escherichia coli and Salmonella typhi, bacteria that cause diarrhea (Adebolu \& Oladimeji, 2005). It also showed larvicide action against Aedes aegypti major vector of dengue fever, and repellent action against Simulium damnosum - the causative agent of Onchocerca volvulus in Nigeria (Cavalcanti et al., 2004; Usip et al., 2006).

The essential oil of clove-basil can be classified in three different chemical groups: eugenol, thymol and geraniol. The eugenol chemotype is the most important economically, with a strong and aromatic perfume with reminiscences of clove, it is distilled in Brazil, Tahiti and Indonesia. Eugenol also attributes to clove-basil antiseptic and local anesthetic actions (Craveiro, 1981), wherefore it is used as dental anesthetic and as a substitute to clove oil, vanillin synthesis and as insect attractive (Farmacopéia, 1959; Merck, 1996).

The regulatory mechanisms of secondary metabolites depend on genetic control which is inherent to the character of each species, but also on external stimulus promoted by the environment (Taiz \& Zeiger, 2004) such as mineral nutrition which can be related to the increasing on the biosynthesis of volatiles (Mairapetyan, 1999). Thus, the evaluation of growth and development of the species cultivated with an alternative residue in addition of phosphorus could provide some subsidies for better conditions of crop and afford opportunities to increase the income of small producers of medicinal plants from the essential oil marketing.

The use of broiler litter is recommended for fertilization since it improves physical and biological properties of the soil and corrects possible deficiencies of macro and micronutrients (Leite et al., 2005). It provides nitrogen, phosphorus and potassium in higher concentrations than manures from other domestic animals, probably explained by dryness once its low concentration of water varies from 5 to $15 \%$ when compared to the others - 65 to $85 \%$. Moreover most of broilers are grown with concentrated rations to supply higher amounts of nutrients (Tedesco et al., 2008).

In Brazil, similar experiments with the species have resulted in good performance of volatiles. Biasi et al. (2009) observed different responses to doses of ram manure on biomass performance during the first harvest. And despite no significant difference regarding to essential oil performance in response to treatments and harvest, there were variations on the composition when it was extracted from leaves and flowers, with average contents of eugenol of $90.4 \%$ in leaves and $80.8 \%$ in flowers.

In a study about the influence of tanned hen manure on biomass yield and oil performance during autumn and winter, Chaves et al. (2002) observed no statistic differences in response to the manure, however there was a greater performance of oil and eugenol content during the autumn (1.29 and $47.33 \%$ ) than in winter (1.08 and $33.73 \%$ ).

Among the macronutrients essential for the plants, the phosphorus shows a great importance as an integral component of cells and as a respiratory and photosynthesis intermediate. It is also part of nucleotides used during energy metabolism as ATP and essential to DNA and RNA synthesis. Phosphorus takes part of several stages of metabolic pathways of essential oils, as an integrant of enzymes responsible for the synthesis of all terpenoids - isopentenyl diphosphate, dimethylallyl diphosphate, etc. (Malavolta, 1997; Taiz \& Zeiger, 2004).

Thus, this experiment aimed to evaluate the biomass yield and the chemical composition of essential oil from clove-basil in response to the use of different doses of broiler litter in absence and addition of phosphorus.

\section{MATERIAL AND METHODS}

Field experiment was carried out at the Garden of Medicinal Plants (22 $11^{\prime} 43.7^{\prime \prime} S$ and $54^{\circ} 56^{\prime} 08.5^{\prime \prime} \mathrm{W}$, altitude of $452 \mathrm{~m}$ ) from the Federal University of Grande Dourados, from March to November, 2009. Climate is a Cwa type (humid mesothermal) (Köppen,1948). Precipitation index during crop season were respectively: 56.0 ; 0.0 ; $56.4 ; 53.4 ; 124.8 ; 140.4 ; 49.7 ; 241$ and 239.9. Maximum and minimum temperatures $\left({ }^{\circ} \mathrm{C}\right)$ were: 32.7 and $20.6 ; 32.3$ and $17.7 ; 28.6$ and $15.7 ; 23.9$ and 11.9; 24.0 and $13.8 ; 27.1$ and $14.9 ; 28.2$ and $16.7 ; 31.2$ and $19.3 ; 33.7$ and 22.7.

The soil of the experimental area is a Red Oxisol (typical Haplortox), very clay texture and plain topography. Chemical characteristics as response to treatments were analyzed two months after crop implantation and are represented in Table 1.

Studied factors were doses of broiler litter $\left(0,5,10,15\right.$ and $\left.20 \mathrm{t} \mathrm{ha}^{-1}\right)$ and phosphorus ( 0.0 and $200 \mathrm{~kg} \mathrm{ha}^{-1} \mathrm{P}_{2} \mathrm{O}_{5}$ ) as triple superphosphate form, both incorporated on the soil the day before transplanting of seedlings. Treatments were ranged as factorial

Rev. Bras. PI. Med., Campinas, v.17, n.1, p.18-25, 2015. 
$5 \times 2$ designed in randomized blocks, with four replications. Each plot had useful area of $2.5 \mathrm{~m}^{2}(2.5$ $\mathrm{m}$ length and $1.0 \mathrm{~m}$ width) with ten plants ranged in double rows of $0.50 \mathrm{~m}$ between plants and rows.

The chemical composition of broiler litter used on the experiment was $30.58 ; 1.6 ; 0.72 ; 3.27$; 0.78 and $3.23 \%$ of $\mathrm{C}_{\text {organic }} ; \mathrm{Ca}_{\text {total }} ; \mathrm{Mg}_{\text {total }} ; \mathrm{P}_{\text {total }} ; \mathrm{K}_{\text {total }}$ and $\mathrm{N}_{\text {total }}$, respectively, and 621.0; 7.1; 728.3; 4,1220.0; $0.15 ; 2.4$ and $9.4 \mathrm{mg} \mathrm{kg}^{-1}$ of $\mathrm{Cu}_{\text {total }} ; \mathrm{Zn}_{\text {total }} ; \mathrm{Mn}_{\text {total }} ; \mathrm{Fe}_{\text {total }}$; $\mathrm{Ni}_{\text {total }} ; \mathrm{Pb}_{\text {total }} \mathrm{C} / \mathrm{N}$ relation was $10 / 1$.

A voucher of clove-basil (Ocimum gratissimum L.) was deposited at DDMS herbarium, under number 4663. Seeds were collected from a parent-plant cultivated at HPM-UFGD. They were sown in polystyrene trays with commercial substrate Bioplant $₫$ and grown in a $50 \%$ shading greenhouse with daily irrigations. After reaching $0.10 \mathrm{~m}$ in height they were transplanted to definitive site.

Before plantation, the site preparation included ploughing and harrowing, afterwards treatments were incorporated with the aid of a bed shaper at a depth of 0-0.20 m. Crop treatments consisted on irrigations by sprinkle system and manual weedings when necessary.

During crop cycle, data on plant height was collected in regular 30 days intervals from 30 until 120 days after transplanting. At 120 days, when flowering stage started, plants were harvested and stems were cut at $0.10 \mathrm{~m}$ from soil level to allow the resprouting. Fresh and dry weight of leaves and stems were evaluated.

After resprouting, plant height were measured at regular 15 days intervals, from 15 until 60 days when a new flowering was observed and a new harvest was done. Yields on fresh and dry weight of leaves, stems and inflorescences were evaluated.

During both harvests, $200 \mathrm{~g}$ of fresh leaves from each plot were used to determine leaf area in a LICOR 3000 integrator. Afterwards the leaves were put in an oven at $60^{\circ} \mathrm{C}$ to dry until constant weight and used to calculate dry matter. Next, samples of dry matter of leaves were powdered and submitted to chemical analysis, using sulfuric digestion for $\mathrm{N}$ and nitric-perchloric for $\mathrm{P}, \mathrm{K}, \mathrm{Ca}, \mathrm{Mg}, \mathrm{Cu}, \mathrm{Fe}, \mathrm{Mn}$ and $\mathrm{Zn}$. Levels of $\mathrm{N}$ was determined using microkjedhal method; P by spectrophotometry $(600 \mathrm{~J}$ Femto); K by flame photometry (B462 Varian) and $\mathrm{Ca}, \mathrm{Mg}$ and micronutrients by atomic absorption spectrophotometry (240FS Varian), according to Malavolta et al. (1997).

Data was subjected to ANOVA and when significant by $\mathrm{F}$ test were submitted to regression analysis, all at $5 \%$ of probability, using SAEG statistic program (Ribeiro Júnior, 2001).

The essential oil was extract at the Laboratory of Medicinal Plants from UFGD and the chromatography analysis was done at the Laboratory

TABLE 1. Chemical characteristics of soil samples collected from experimental area two months after the addition of broiler litter and phosphorus.

\begin{tabular}{|c|c|c|c|c|c|c|c|c|c|c|}
\hline \multirow{3}{*}{ Characteristic ${ }^{\mathrm{s}} /$} & \multicolumn{10}{|c|}{ Doses of broiler litter ( $\mathrm{t}$ ha-1)/Absence $(\mathrm{OP})$ or Presence of $\mathrm{P}(\mathrm{P})\left(200 \mathrm{~kg} \mathrm{ha}^{-1}\right.$ of $\left.\mathrm{P}_{2} \mathrm{O}_{5}\right)$. } \\
\hline & \multicolumn{3}{|c|}{0} & \multicolumn{2}{|l|}{5} & \multicolumn{2}{|l|}{10} & \multirow{2}{*}{$\begin{array}{r}15 \\
P \\
\end{array}$} & \multicolumn{2}{|r|}{20} \\
\hline & $\mathrm{OP}$ & $\mathrm{P}$ & OP & $\mathrm{P}$ & $\mathrm{OP}$ & $\mathrm{P}$ & $\mathrm{OP}$ & & $\mathrm{OP}$ & $P$ \\
\hline $\mathrm{pH} \mathrm{CaCl}_{2}$ & 5,1 & 4,8 & 4,9 & 4,5 & 5,0 & 4,7 & 5,1 & 5,1 & 5,4 & 5,2 \\
\hline $\mathrm{pH} \mathrm{H}_{2} \mathrm{O}(1: 2,5)$ & 5,9 & 5,7 & 5,7 & 5,3 & 5,9 & 5,6 & 5,8 & 5,9 & 6,0 & 5,7 \\
\hline $\mathrm{Al}^{+3}\left(\mathrm{mmol}_{\mathrm{c}} \mathrm{dm}^{-3}\right)^{21}$ & 0,0 & 1,2 & 1,2 & 2,5 & 0,0 & 1,2 & 0,6 & 0,0 & 0,0 & 0,6 \\
\hline $\mathrm{P}\left(\mathrm{mg} \mathrm{dm}^{-3}\right) 2 /$ & 34,0 & 61,0 & 54,0 & 54,0 & 86,0 & 73,0 & 96,0 & 137,0 & 160,0 & 165,0 \\
\hline $\mathrm{K}\left(\mathrm{mmol}_{\mathrm{c}} \mathrm{dm}^{-3}\right)^{2 /}$ & 7,7 & 6,8 & 9,2 & 9,2 & 10,7 & 11,4 & 13,5 & 12,9 & 16,0 & 16,0 \\
\hline $\mathrm{Mg}\left(\mathrm{mmol}_{\mathrm{c}} \mathrm{dm}^{-3}\right)^{2 /}$ & 19,0 & 16,0 & 19,0 & 13,0 & 23,0 & 18,0 & 18,0 & 23,0 & 23,0 & 21,0 \\
\hline $\mathrm{Ca}\left(\mathrm{mmol}_{\mathrm{c}} \mathrm{dm}^{-3}\right)^{2 /}$ & 40,0 & 38,0 & 42,0 & 32,0 & 48,0 & 41,0 & 41,0 & 52,0 & 49,0 & 47,0 \\
\hline $\mathrm{Cu}\left(\mathrm{mg} \mathrm{dm}^{-3}\right)^{2 /}$ & 18,0 & 17,2 & 18,2 & 16,4 & 18,4 & 18,1 & 17,8 & 19,3 & 18,4 & 18,6 \\
\hline $\mathrm{Mn}\left(\mathrm{mg} \mathrm{dm}^{-3}\right)^{2 /}$ & 65,6 & 55,0 & 63,7 & 43,8 & 73,9 & 69,1 & 68,6 & 87,1 & 84,8 & 77,0 \\
\hline $\mathrm{Fe}\left(\mathrm{mg} \mathrm{dm}^{-3}\right)^{2 /}$ & 77,3 & 71,3 & 76,2 & 66,8 & 69,8 & 68,3 & 55,7 & 61,9 & 56,1 & 72,8 \\
\hline $\mathrm{Zn}\left(\mathrm{mg} \mathrm{dm}^{-3}\right)^{2 /}$ & 5,6 & 5,8 & 7,8 & 6,5 & 10,4 & 9,1 & 10,8 & 13,3 & 17,2 & 17,3 \\
\hline M.O. $\left(\mathrm{g} \mathrm{dm}^{-3}\right)^{21}$ & 29,0 & 26,5 & 28,4 & 27,7 & 29,0 & 29,0 & 29,0 & 32,2 & 33,4 & 32,2 \\
\hline$(\mathrm{H}+\mathrm{Al})\left(\mathrm{mmol}_{\mathrm{c}} \mathrm{dm}^{-3}\right)$ & 58,0 & 62,0 & 62,0 & 80,0 & 53,0 & 62,0 & 58,0 & 53,0 & 47,0 & 55,0 \\
\hline S.B. $\left(\mathrm{mmol}_{\mathrm{c}} \mathrm{dm}^{-3}\right)$ & 66,7 & 60,8 & 70,2 & 54,2 & 81,7 & 70,4 & 72,5 & 87,9 & 88,0 & 84,0 \\
\hline CTC $\left(\mathrm{mmol}_{\mathrm{c}} \mathrm{dm}^{-3}\right)$ & 124,7 & 122,8 & 132,2 & 134,2 & 134,7 & 132,4 & 130,5 & 140,9 & 135,0 & 139,0 \\
\hline Base saturation (\%) & 53 & 49 & 53 & 40 & 60 & 53 & 55 & 62 & 65 & 60 \\
\hline
\end{tabular}

"Analysis done in the Soil Laboratory, of the Agrarian Science Faculty (FCA) - UFGD

${ }^{2 /}$ EMBRAPA (1997)

Rev. Bras. PI. Med., Campinas, v.17, n.1, p.18-25, 2015. 
of Chemistry of the Federal University of Mato Grosso do Sul (UFMS). Fresh leaves (200g) from each treatment were subjected to hydrodistillation for 4 hours in a Clevenger-type apparatus, according to methodology proposed by Charles \& Simon (1990). The total volume of the oil was obtained and the samples were stored in sterile microtubules at -10 ${ }^{\circ} \mathrm{C}$ until further analysis. The content was calculated using the formula: Content $=v(\mathrm{~mL}) \times 100 \mathrm{~m}^{-1}(\mathrm{~g})$, where $v$ is the volume obtained in milliliters, and $\mathrm{m}$ is the dry weight in gram.

Chemical analysis were performed on a gas chromatograph (GC 3900) equipped with ion-trap mass spectrometer detector (Varian Saturn 2100) using DB-5 (5\% phenyl dimethylpolysiloxane), fused silica column $(30 \mathrm{~m} \times 0,25 \mathrm{~mm}, 0,25 \mu \mathrm{m}$ film thickness) under the following conditions: carrier gas helium $\left(99,999 \%\right.$ and flow rate $\left.1.0 \mathrm{~mL} \mathrm{~min}^{-1}\right) ; 1 \mu \mathrm{L}$ injection volume, split ratio (1:20), with initial oven temperature of $50^{\circ} \mathrm{C}$ and heating from $50^{\circ}$ to $250^{\circ} \mathrm{C}$ at $3^{\circ} \mathrm{C} / \mathrm{min}$. Injector and detector and transfer line temperatures were $240^{\circ} \mathrm{C}$. The MS scan parameters included electron impact ionization voltage at $70 \mathrm{eV}$, a mass range of 40 to $450 \mathrm{~m} / \mathrm{z}$ and a scan interval of $0.5 \mathrm{~s}$. Temperature-programmed retention indices were calculated using a mixture of $\mathrm{n}$-alkane standard $\left(\mathrm{C}_{8}-\mathrm{C}_{22}\right)$ as external references (Zhao et al., 2005). The identifications were completed by comparing the mass spectra obtained in the MS 2.0 data processor with database of NIST/02 with 147.198 mass spectra and literature data (Adams, 2001).

Determination of the relative area by GC/FID analysis was performed using a gas chromatograph with flame ionization detector (Thermo Scientific Focus GC, San Jose, CA, USA) equipped with the same DB-5 fused silica column capillary under the following conditions: carrier gas $\mathrm{N}_{2}(99.999 \%$, and flow rate of $\left.1.0 \mathrm{~mL} \mathrm{~min}^{-1}\right), 1 \mu \mathrm{L}$ injection volume, split ratio $(1: 20)$ with initial oven temperature of $50^{\circ} \mathrm{C}$ and heating from $50^{\circ}$ to $250^{\circ} \mathrm{C}$ at $3^{\circ} \mathrm{C} \mathrm{min}$ m. The injector $^{-1}$ and detector were kept at a temperature of $240^{\circ} \mathrm{C}$. The chromatograms were recorded with the Chrom Quest 5.0 software, and analyzed by means of the Workstation Chrom Data Review software.

\section{RESULTS AND DISCUSSION}

The height of the plants during the first vegetative cycle was not significantly influenced by interaction between doses of broiler litter and phosphate. However there were significant responses for the individual use of phosphate (Figure 1a) and broiler litter (Figure 1b) as functions of evaluation date.

The maximum heights observed were 32.4 $\mathrm{cm}$ with no use of phosphate nor litter and $34.4 \mathrm{~cm}$ using 15 ton ha-1 of broiler litter and no phosphorus, all at 120 days after transplanting. The smallest heights of plants in presence of phosphorus can be due to the plants use more photosynthates for leaf production which could be evidenced since leaf areas were higher in the presence of that nutrient (Table 2). That can be explained once P works as a regulator of photosynthesis and metabolism and it's responsible by partition of assimilates through the leaves (Marschner, 1995). On the other hand, a positive effect on the use of broiler litter was probably due to its capacity of keeping humidity of soil surface as well as promoting water infiltration, increasing availability of nutrients and preserving the bio-structure of the soil (Souza, 1998). Costa
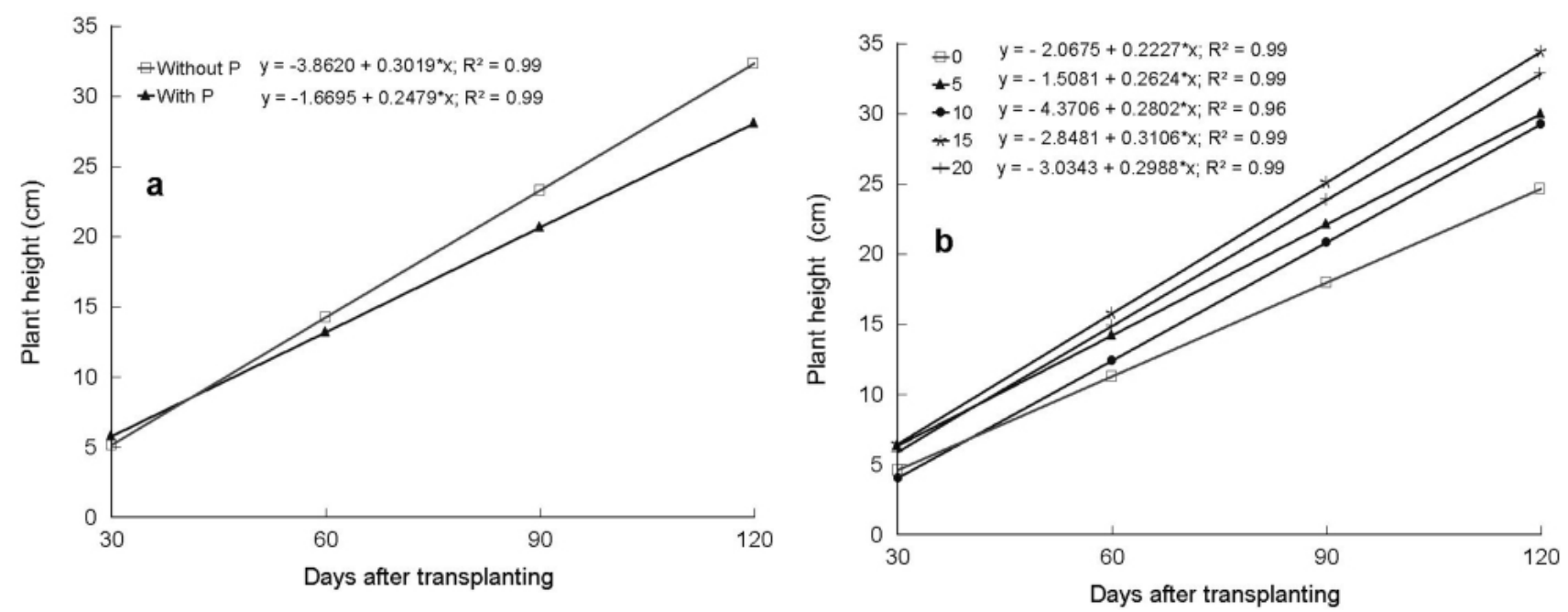

FIGURE 1. Height of clove-basil in response to the addition of phosphorus (a) and five doses of broiler litter (b). 
et al. (2008) also observed increases on height of Ocimum selloi as consequence of increased doses of cattle manure, with maximum height of $67.3 \mathrm{~cm}$ when applying $8 \mathrm{~kg} \mathrm{~m}^{-2}$.

Plant height after resprouting was not influenced by additions of broiler litter neither by the phosphate. The maximum height $(76.0 \mathrm{~cm})$ was observed at 60 days after the first harvest. Maximum height after resprouting was $41.6 \mathrm{~cm}$ superior compared to those obtained during the first cycle. Those differences between the first cycle and after resprouting occurred because plants had already developed root system and used most part of photosynthates for development of aerial part. The results from this experiment are similar to those from Blank et al. (2005) who, evaluating the effects of organic and chemical fertilizations on Ocimum basilicum, did not find a correlation of doses and plant height, obtaining average of $36.9 \mathrm{~cm}$.

Fresh and dry weight of leaves, stems and inflorescences as well as the leaf area obtained during the first harvest and after resprouting were not statistically influenced by interaction between doses of broiler litter and phosphate (Figure 2). However, during the first harvest, the use of broiler litter significantly influenced yields on fresh and dry weight of leaves and fresh weight of stems which increased linearly in response to higher doses (Figure 2a).

Likewise, after resprouting yields on fresh weight of leaves, fresh and dry weight of stems and leaf areas (Figure 2b) showed linear increases in response to higher doses of broiler litter.

The highest yields were obtained using 20

TABLE 2. Fresh and dry matter of leaves, stems and inflorescences and leaf area of clove-basil in response to phosphate fertilization during the first harvest and after resprouting.

\begin{tabular}{|c|c|c|c|c|}
\hline Phosphorus & \multicolumn{4}{|c|}{ Fresh weight (kg ha-1) } \\
\hline $200 \mathrm{~kg} \mathrm{ha}^{-1} \mathrm{P}_{20} 5$ & Leaf & Stem & Inflorescence & Leaf area $\mathrm{cm}^{2} /$ plant \\
\hline Harvest 1 without & $1.159,34 \mathrm{a}$ & $588,29 a$ & - & $1.357,69 \mathrm{~b}$ \\
\hline With & $1.342,04 \mathrm{a}$ & 766,35 a & - & $1.771,00 \mathrm{a}$ \\
\hline C.V. $(\%)$ & 33,55 & 46,50 & - & 39,20 \\
\hline Harvest 2 without & $5.805,56 \mathrm{a}$ & $4.137,12 \mathrm{a}$ & $1.629,29 \mathrm{a}$ & $6.855,99 a$ \\
\hline With & $6.346,29 a$ & $4.468,99$ a & $1.848,73 a$ & $7.442,99 \mathrm{a}$ \\
\hline C.V. $(\%)$ & 20,20 & 21,25 & 23,90 & 19,73 \\
\hline \multicolumn{5}{|c|}{ Dry weight $(\mathrm{kg} \mathrm{ha-1})$} \\
\hline Harvest 1 without & $256,04 \mathrm{a}$ & $133,25 \mathrm{a}$ & - & - \\
\hline With & 263,34 a & $153,45 a$ & - & - \\
\hline C.V. $(\%)$ & 35,33 & 61,90 & - & - \\
\hline Harvest 2 without & $1.274,61 \mathrm{a}$ & $1.397,70 \mathrm{a}$ & $458,70 \mathrm{a}$ & - \\
\hline With & $1.400,52 \mathrm{a}$ & $1.470,35 \mathrm{a}$ & $515,99 a$ & - \\
\hline C.V. $(\%)$ & 26,35 & 22,32 & 26,91 & - \\
\hline
\end{tabular}

Means followed by the same letters in the same column did not differ statistically by $\mathrm{F}$ test, at $5 \%$ of probability.
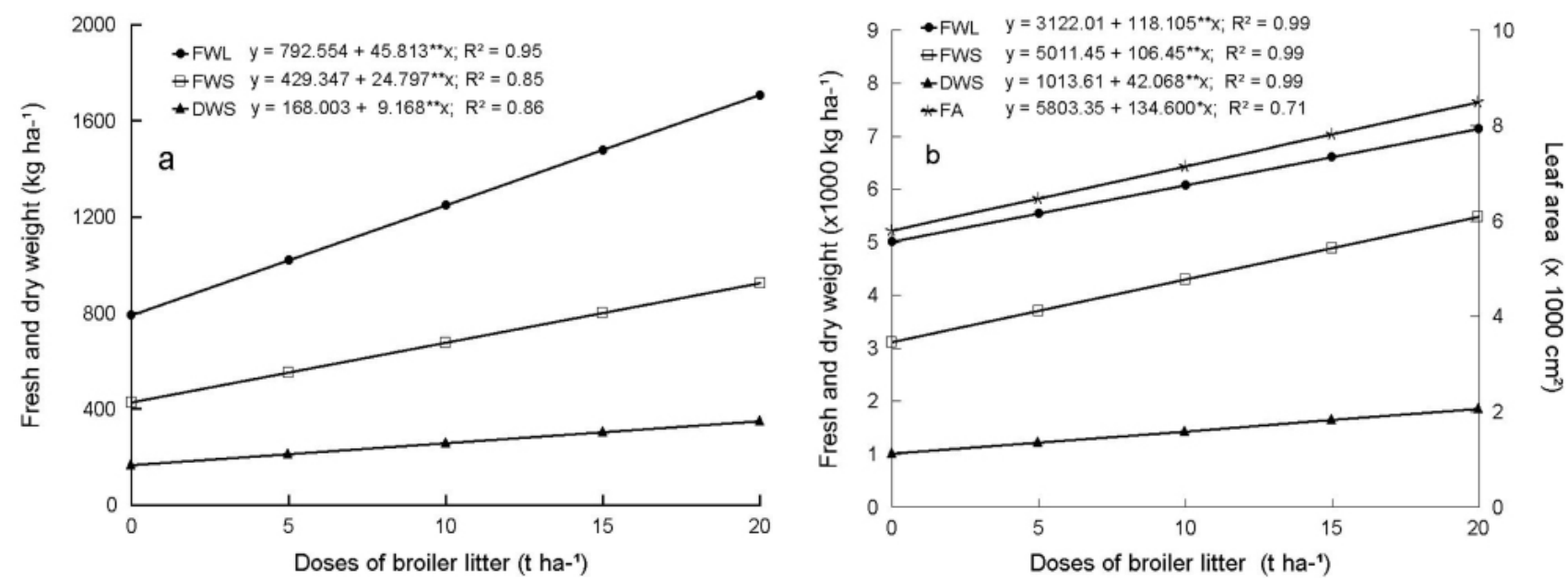

FIGURE 2. Fresh (MFF) and dry (MSF) weight of leaves; fresh (MFC) and dry (MSC) weight of stems and leaf area (FA) of clove-basil in response to different doses of broiler litter during first harvest (a) and after re-sprouting (b).

Rev. Bras. PI. Med., Campinas, v.17, n.1, p.18-25, 2015. 
ton ha-1 of broiler litter, resulting on 1,708.82 and $7,140.41 \mathrm{~kg} \mathrm{ha}^{-1}$ of fresh weight of leaves and 925.29 and $5,484.11 \mathrm{~kg} \mathrm{ha}^{-1}$ of fresh weight of stems, during first harvest and resprouting, respectively.

Differences among dry weights of leaves (351.37 kg ha-1) in response to the doses of broiler litter were significant only during the first harvest, and dry weights of stems $\left(1,854.80 \mathrm{~kg} \mathrm{ha}^{-1}\right)$ and leaf area $\left(8,495.35 \mathrm{~cm}^{2}\right.$ plant-1) only after the resprouting, all of them using 20 ton ha-1.

The highest yields in response to the highest doses of broiler litter were possible due to its chemical properties as supplier of nutrients, as well to its capacity to improve the physical structure of the soil, increasing retention of water and decreasing loses by erosion. Furthermore, the residue can supply biological control besides it increases microbial population and improve the buffer capacity of the soil (Kiehl, 2008).

Leaf area responded significantly to the use of phosphate during the first harvest only, with maximal result superior $413.31 \mathrm{~cm}^{2}$ plant-1 than plants without it (Table 2). After resprouting the average leaf area was $7,149.49 \mathrm{~cm}^{2}$ plant-1. This lack of answer to the addition of phosphate allows us to assume the use of semi-decomposed broiler litter was enough to supply the $P$ necessity in every treatment.

There was significant interaction between doses of broiler litter and phosphate only for magnesium and nitrogen contents from leaves. The contents of $\mathrm{Mg}$ as function of doses of broiler litter did not adjust to regression models, resulting in average $4.60 \mathrm{~g} \mathrm{~kg}^{-1}$ without the use of phosphate and $4.72 \mathrm{~g}$ $\mathrm{kg}^{-1}$ with the addition of phosphate (Table 3 ).

Maximum content of $\mathrm{N}\left(33.22 \mathrm{~g} \mathrm{~kg}^{-1}\right)$ without the addition of phosphate was obtained in response to 9.2 ton ha-1 of broiler litter, while with the use of phosphate the average content was $32.55 \mathrm{~g} \mathrm{~kg}^{-1}$.

Although $\mathrm{K}$ had been influenced significantly by the addition of phosphate in soil and $\mathrm{Mn}$ and $\mathrm{Zn}$ by broiler litter, data were not adjusted to any of tested models. Further nutrients were not influenced by the use of phosphate neither by the doses of broiler litter.

Contents of essential oil from the leaves of clove-basil did not vary in response to the treatments, with average $0.70 \%$ (C.V. $17.13 \%$ ). Probably, this feature is poorly responsive to the use of manures and, although its recognized advantages to vegetative development, very few studies show relations between $\mathrm{pH}$ or micro-organisms on the soil and secondary metabolism of plants (Evans, 1996). This result is similar to those observed by Chaves et al. (2002) and Biasi et al. (2009), who evaluated the effects of crescent doses of organic fertilization on Ocimum gratissimum and could not observe any difference on the essential oil contents. However the average content obtained by the authors was superior compared to this work (1 and $1.08 \%$ respectively).

Unlike, the performance of essential oil increased linearly in response to the doses of broiler litter with maximum performance (3.8 $\left.\mathrm{L} \mathrm{ha}^{-1}\right)$ under 20 ton ha-1. This response is a reflection of positive effects of the residue on the biomass yield which was also increased by the raising on the doses of broiler litter. On the other hand, Biasi et al. (2009) did not observe any difference on the performance of essential oil from leaves of clove basil, with average performance of $4.04 \mathrm{~L} \mathrm{ha}^{-1}$ after resprouting.

Oil analysis identified 42 compounds and among them six represented about $94 \%$ from the total (Table 4). Concentrations of eugenol varied from 67.30 to $74.99 \%$. Eugenol content was superior than those found by Chaves et al. (2002) and Jirovetz et al. (2003), who found values inferior to $63.36 \%$ to different dates of extraction.

Other major compounds (Table 4) were sesquiterpenes: $\beta$-selinene (8.18 to $8.27 \%$ ), $\beta$-ilangene $(4.97$ to $5.09 \%)$, viridiflorene $(3.38$ $3.47 \%$ ); the monoterpene 1.8 cineol (3.07 to $3.11 \%)$ and $\mathrm{y}$-himachalene $(2.00-2.62 \%)$. Further 36 compounds were identified in concentrations lower than $1 \%$. These data were different from those found by Chaves et al. (2002) who studied the same species under environmental conditions from Botucatu-SP and identified as major compounds with lower levels than eugenol: 1.8-cineol (23.73\%), cis-ocimene $(4.25 \%)$, $\beta$-selinene $(6.93 \%)$ and transcaryophyllene $(5.13 \%)$.

TABLE 3. Averages of nutrient contents found in dry leaves of clove-basil harvested after re-sprouting in response to the addition of phosphate on the soil.

\begin{tabular}{|c|c|c|c|c|c|c|c|c|}
\hline $\begin{array}{l}P \\
\left(200 \mathrm{~kg} \mathrm{ha}^{-1} \mathrm{P}_{2} \mathrm{O}_{5}\right)\end{array}$ & $\mathrm{N}$ & $\mathrm{P}$ & $\mathrm{K}$ & $\mathrm{Ca}$ & $\mathrm{Mg}$ & $\mathrm{Mn}$ & $\mathrm{Fe}$ & $\mathrm{Zn}$ \\
\hline & & $\mathrm{g} \mathrm{kg}^{-1}$ & & & & $\mathrm{mg} \mathrm{kg}^{-1}$ & & \\
\hline Without $P$ & $32,03 \mathrm{~b}$ & $2,78 \mathrm{a}$ & $1,51 \mathrm{a}$ & $\overline{19,56 a}$ & $4,60 \mathrm{~b}$ & $120,17 \mathrm{a}$ & 1147,53 a & $20,27 a$ \\
\hline With P & $32,55 \mathrm{a}$ & $2,98 a$ & $1,66 \mathrm{a}$ & $18,87 a$ & $4,72 a$ & $101,92 a$ & $1231,60 a$ & 20,96 a \\
\hline C.V. $(\%)$ & 3,94 & 14,41 & 9,77 & 14,62 & 6,27 & 29,03 & 15,48 & 11,18 \\
\hline
\end{tabular}

Means followed by the same letters in same columns did not differ by $\mathrm{F}$ test at $5 \%$ probability. 
TABLE 4. Chemical compounds (\%) identified in the essential oil extracted from leaves of clove-basil in response to doses of broiler litter in absence (without $\mathrm{P}$ ) and presence of phosphorus (with $\mathrm{P})\left(200 \mathrm{~kg} \mathrm{ha}^{-1} \mathrm{de}^{\mathrm{P}_{2} \mathrm{O}_{5}}\right.$ ).

\begin{tabular}{|c|c|c|c|c|c|c|}
\hline \multirow[b]{2}{*}{$I^{a}$} & \multirow[b]{2}{*}{ Compound* } & \multicolumn{5}{|c|}{ Broiller litter (t ha-1) Without $P$} \\
\hline & & 0 & 5 & 10 & 15 & 20 \\
\hline 1031 & 1,8 cineol & 3,07 & 3,09 & 3,10 & 3,13 & 3,09 \\
\hline 1359 & Eugenol & 67,30 & 68,30 & 69,33 & 70,45 & 70,96 \\
\hline 1421 & $\beta$-ilangeno & 4,95 & 4,97 & 4,99 & 4,99 & 4,99 \\
\hline 1483 & Y-himachaleno & 2,00 & 2,62 & 2,62 & 2,62 & 2,62 \\
\hline 1490 & $\beta$-selineno & 8,18 & 8,20 & 8,21 & 8,22 & 8,23 \\
\hline \multirow[t]{2}{*}{1497} & Viridifloreno & 3,38 & 3,39 & 3,40 & 3,41 & 3,42 \\
\hline & & \multicolumn{5}{|c|}{ Broiller litter ( $\mathrm{t} \mathrm{ha}^{-1}$ ) With $\mathrm{P}$} \\
\hline $\mathrm{IR}^{\mathrm{a}}$ & Compound* & 0 & 5 & 10 & 15 & 20 \\
\hline 1031 & 1,8 cineol & 3,08 & 3,09 & 3,10 & 3,11 & 3,12 \\
\hline 1359 & Eugenol & 72,56 & 73,89 & 74,08 & 74,67 & 74,99 \\
\hline 1421 & $\beta$-ilangeno & 5,05 & 5,05 & 5,05 & 5,07 & 5,09 \\
\hline 1483 & y-himachaleno & 2,62 & 2,62 & 2,62 & 2,62 & 2,62 \\
\hline 1490 & $\beta$-selineno & 8,22 & 8,23 & 8,25 & 8,26 & 8,27 \\
\hline 1497 & Viridifloreno & 3,43 & 3,43 & 3,44 & 3,45 & 3,47 \\
\hline
\end{tabular}

alndex of kovàts; *36 constituting inferiors to $1 \%$.

\section{CONCLUSION}

Under the same environmental conditions of this experiment, it is recommended the use of 20 ton ha-1 ${ }^{-1}$ broiler litter, regardless the use of phosphate, for increasing on biomass yield and higher performance on essential oil of clove-basil. The chemical composition of essential oil was not influenced by the doses of broiler litter neither by the use of phosphate, nevertheless showed higher quantity of eugenol.

\section{ACKNOWLEDGMENTS}

The authors are grateful to CNPq, by scholarships and FUNDECT-MS, for financial support.

\section{REFERENCES}

ADAMS, R.P. Identification of essential oil components by gas chromatography /quadrupole mass spectroscopy. Carol Stream: Allured, 2001. 456p.

ADEBOLU, T.T.; OLADIMEJI, S.A. Antimicrobial activity of leaf extracts of Ocimum gratissimum on selected diarrhoea causing bacteria in southwestern Nigeria. African Journal of Biotechnology, v.4, n.7, p.682684, 2005.

ALBUQUERQUE, U.P.; ANDRADE, L.H.C. El género Ocimum L. (Lamiaceae) en el nordeste del Brasil. Anales del Jardín Botánico de Madrid, v.56, n.1, p.43-64, 1998.

BIASI, L.A.; MACHADO, E.M.; KOWALSKI, A.P.J.; SIGNOR, D.; ALVES, M.A.; LIMA, F.I.; DESCHAMPS, C.; CÔCCO, L.C.; SCHEER, A.P. Adubação orgânica na produção, rendimento e composição do óleo essencial da alfavaca-cravo quimiotipo eugenol. Horticultura Brasileira, v.27, n.1, p.35-39, 2009.

BLANK, A.F.; SILVA, P.A.; ARRIGONI-BLANK, M.F.; SILVA-MANN, R.; VASCONCELOS, M.C. Influência da adubação orgânica e mineral no cultivo de manjericão cv. Genovese. Revista Ciência Agronômica, v.36, n.2, p.175-180, 2005.

CAVALCANTI, E.S.B.; MORAIS, S.M.; LIMA, M.A.A.; SANTANA, E.W.P. Larvicidal activity of essential oils from Brazilian plants against Aedes aegypti L. Memórias do Instituto Oswaldo Cruz, v.99, n.5, p.541-544, 2004.

CHARLES, D.J.; SIMON, J.E. Comparison of extraction methods for the rapid determination of essential oil content and composition of basil. Journal of the American Society of Horticultural Science, v.115, n.3, p.458-462, 1990.

CHAVES, F.C.M.; MING, L.C.; EHLERT, P.A.D. Influence of organic fertilization on leaves and essencial oil production of Ocimum gratissimum L. Acta Horticulturae, n.576, p.273-275, 2002.

COSTA, L.C.B.; PINTO, J.E.B.; CASTRO, E.M.; BERTOLUCCI, S.K.V.; CORREAA, R.M.; REIS, E.S.; ALVES, P.B.; NICULAU, E.S. Tipos e doses de adubação orgânica no crescimento, no rendimento e na composição química do óleo essencial de elixir paregórico. Ciência Rural, v.38, n.8, p.2173-2180, 2008.

CRAVEIRO, A.A.; FERNANDES, A.G.; ANDRADE, C.H.S.; MATOS, F.J.A.;

ALENCAR, J.W.; MACHADO, M.I.L. Óleos essenciais de plantas do Nordeste, Fortaleza: Editora da Universidade Federal do Ceará, 1981. 210p.

EFFRAIM, K.D.; JACKS, T.W.; SODIPO, O.A. Histopathological studies on the toxicity of Ocimum gratissimum leave extract on some organs of rabbit. Journal Biomedical Research, v.6, n.1, p.21-25, 2001. EMPRESABRASILEIRADE PESQUISAAGROPECUÁRIA - EMBRAPA. Centro Nacional de Pesquisas de Solos. 1997. Manual de métodos de análises de solo, 2.ed. Rio de Janeiro: EMBRAPA, 1997. 212p. 
EVANS, W.C. Trease and Evans' Pharmacognosy, 14.ed. London: WB Saunders Company, 1996. p.388433.

FARMACOPÉIA dos Estados Unidos do Brasil. 2.ed. São Paulo: Siqueira, 1959. p.327-328.

JIROVETZ, L.; BUCHBAUER, G.; SHAFI, M.P.; KANIAMPADY, M.M. Chemotaxonomical analysis of the essential oil aroma compounds of four different Ocimum species from southern India. European Food Research and Technology, v. 217, n.2, p.120-124, 2003.

KIEHL, E.J. Adubação orgânica: 500 perguntas e respostas. Piracicaba: Editora Degaspari, 2008. 227p.

KÖPPEN, W. Climatologia: con un estudio de los climas de la tierra. México: Fondo de Cultura Económica, 1948. 479p.

LEITE, G.L.D.; ARAÚJO, C.B.O.; AMORIM, C.A.D.; PÊGO, K.P.; MARTINS, E.R.; SANTOS, E.A.M. Níveis de adubação orgânica na produção de calêndula e artrópodes associados. Arquivos do Instituto Biológico, v.72, n.2, p.227-233, 2005.

MAIRAPETYAN, S.K. Aromatic plant culture in open - air hydroponics. Acta Horticulturae, n.502, p.33-36, 1999.

MALAVOLTA, E.; VITTI, G.C.; OLIVEIRA, S.A. Avaliação do estado nutricional das plantas: princípios e aplicações. Piracicaba: Potafós, 1997. 319p.

MARSCHNER, H. Mineral nutrition of higher plants, 2.ed. London: Academic Press, 1995. 889p.

RIBEIRO JÚNIOR, J.I. Análises estatísticas no SAEG. Viçosa: UFV, 2001. 301p.

SOUZA, J.L. Agricultura orgânica: tecnologias para a produção de alimentos saudáveis. Vitória: Emcapa, 1998. 188p.

TAIZ, L.; ZEIGER, E. Fisiologia Vegetal. Porto Alegre: Artes Médicas, 2004. 820p.

TEDESCO, M.J.; SELBACH, P.A.; GIANELLO, C. CAMARGO, F.A.O. Resíduos orgânicos no solo e os impactos no ambiente. In: SANTOS, G.A.; SILVA, L.S.; CANELLAS, L.P.; CAMARGO, F.A.O. Fundamentos da matéria orgânica do solo: ecossistemas tropicais e subtropicais. 2.ed. Porto Alegre: Metrópole, 2008. p.113-136.

MERCK index. 12. ed. New York: Merck, 1996. 1741p.

USIP, L.P.E.; OPARA, K.N.; IBANGA, E.S.; ATTING, I.A. Longitudinal evalution of repellent activity of Ocimum gratissimum (Labiatae) volatile oil against Simulium damnosum. Memórias do Instituto Oswaldo Cruz, v.101, n.2, p.201-205, 2006.

ZHAO, C.X.; LIANG, Y.Z.; FANG, H.Z.; LI, X.N. Temperature-programmed retention indices for gas chromatography-mass spectroscopy analysis of plant essential oils. Journal Chromatography, v.1096, n.12, p.76-85, 2005.

Rev. Bras. PI. Med., Campinas, v.17, n.1, p.18-25, 2015. 